\title{
Pengaruh Mutasi Fisik Iradiasi Sinar Gamma terhadap Keragaman Genetik dan Penampilan Coleus blumei
}

\author{
Effect of Physical Mutation by Gamma Ray Irradiation on Genetic Variability \\ and Performance of Coleus $\underline{\text { blumei }}$
}

\author{
Eny Rolenti Togatorop ${ }^{1}$, Syarifah Iis Aisyah ${ }^{2 *}$, dan M. Rizal M. Damanik ${ }^{3}$
}

Diterima 27 Maret 2016/Disetujui 26 Oktober 2016

\begin{abstract}
Mutation breeding such as gamma ray irradiation is one of strategy to increase genetic variability. The aim of this research was to indentify genetic variability, performance changes and to obtain putative mutant of Coleus blumei purple/green through gamma ray irradiation. The experiment design used was Randomized Complete Block with single factor and three replications. The gamma ray irradiation was given to shoot cuttings of $\underline{C}$. blumei by fractionated irradiation dose: 0 Gy (control), 20+20 Gy, 22.5+22.5 Gy, 25+25 Gy and 27.5+27.5 Gy. The irradiated shoot cuttings were planted in field until MV3 generation. The result of this research showed that gamma ray irradiation on C.blumei purple/green produced the high genetic variability on number of leaves and number of branches i.e. $58.48 \%$ and $74.02 \%$ by $25+25$ Gy dose and number of branches by $20+20$ Gy and $22.5+22.5$ Gy dose i.e. $53.47 \%$ and $68.97 \%$ respectively. Physically induced mutation by gamma ray irradiation produced 5 putative mutants respectively on colour and pattern of leaf changes in the following plants: $20+20.5,20+20.7,22.5+22.5 .8,25+25.5$ and $25+25.8$.
\end{abstract}

Keywords: fractionated irradiation, mutagen, ornamental plant, putative mutan, shoot cutting

\begin{abstract}
ABSTRAK
Pemuliaan mutasi dengan iradiasi sinar gamma merupakan salah satu cara dalam meningkatkan keragaman genetik tanaman. Tujuan penelitian ini untuk mengidentifikasi keragaman genetik, perubahan penampilan dan mendapatkan mutan putatif pada tanaman Coleus blumei ungu/hijau melalui iradiasi sinar gamma. Penelitian menggunakan rancangan kelompok lengkap teracak (RKLT) faktor tunggal dengan 3 ulangan. Iradiasi sinar gamma diberikan terhadap stek pucuk C. blumei ungu/hijau dengan dosis terbagi yaitu: 0 Gy (kontrol), 20+20 Gy, 22.5+22.5 Gy, $25+25$ Gy dan $27.5+27.5$ Gy. Semua tanaman hasil iradiasi ditanam di lapangan sampai generasi MV3. Hasil penelitian menunjukkan bahwa pemberian iradiasi sinar gamma pada C. blumei ungu/hijau menghasilkan keragaman genetik yang cukup tinggi pada karakter jumlah daun dan jumlah cabang dengan nilai KKG masing-masing $58.48 \%$ dan $74.02 \%$ pada dosis $25+25$ Gy serta karakter jumlah cabang dengan nilai KKG $53.47 \%$ dan $68.97 \%$ masing-masing pada dosis $20+20$ gy dan $22.5+22.5 \mathrm{~Gy}$. Mutasi induksi fisik dengan iradiasi sinar gamma pada C. blumei ungu/hijau menghasilkan 5 mutan putatif berdasarkan perubahan warna dan corak daun yaitu pada tanaman: $20+20.5,20+20.7,22.5+22.5 .8,25+25.5$ dan $25+25.8$.
\end{abstract}

Kata kunci: iradiasi terbagi, mutagen, mutan putatif, stek pucuk, tanaman hias

\footnotetext{
${ }^{1}$ Sekolah Pascasarjana, Institut Pertanian Bogor Kampus IPB Darmaga, Bogor 16680, Indonesia ${ }^{2}$ Departemen Agronomi dan Hortikultura, Fakultas Pertanian, Institut Pertanian Bogor Jl. Meranti, Kampus IPB Darmaga, Bogor 16680, Indonesia

${ }^{3}$ Departemen Gizi Masyarakat, Fakultas Ekologi Manusia, Institut Pertanian Bogor

Jl. Lingkar Akademik, Kampus IPB Darmaga, Bogor 16680, Indonesia

E-mail: syarifahiis@yahoo.com (*penulis korespondensi)
} 


\section{PENDAHULUAN}

Coleus blumei merupakan jenis tanaman famili Lamiaceae yang tergolong ke dalam tanaman hias (Loutfy et al., 2013). Coleus blumei (C. blumei) dapat dikembangkan sebagai tanaman hias karena variasi bentuk dan warna daunnya yang beragam (Rumbiak $e t$ al., 2009). Dalam satu daun C. blumei bisa terdapat warna yang berbeda seperti warna ungu yang dibingkai dengan warna hijau dan kuning ataupun warna lain seperti merah, jingga, cokelat dan merah muda (Chung dan Choi, 2008). Di Indonesia, tanaman hias sudah menjadi industri penting yang diminati dan memiliki dampak komersial. Industri tersebut semakin berkembang seiring dengan perubahan polaperilaku masyarakat yang selalu mengikuti perubahan zaman. Hal ini telah terbukti dengan semakin berkembangnya pemanfaatan tanaman hias yang ditujukan untuk tatanan kota maupun keindahan lingkungan sekitar rumah (Handayati, 2013). Sebagai tanaman hias, pengembangan tanaman C. blumei dengan merakit keragaman baru akan menambah daya tarik bagi konsumen.

Mutasi merupakan teknik yang tepat untuk merakit keragaman baru pada tanaman yang berbiak secara vegetatif seperti stek pucuk karena sel-selnya sedang aktif membelah (Datta, 2012). Mutasi dapat diinduksi secara buatan dengan mutagen fisik melalui iradiasi sinar gamma (Djajanegara $e t$ al., 2007). Menurut Suprasanna (2013) mutasi induksi dengan iradiasi sinar gamma pada tanaman berbiak vegetatif dapat diterapkan pada tanaman mint, tanaman berkayu, tanaman berumbi maupun tanaman hias. Mutasi merupakan metode yang paling mudah untuk mendapatkan keragaman genetik dibandingkan dengan metode pemuliaan yang lain karena kemampuannya dalam mengubah beberapa karakter, selain itu mampu mendapatkan sifatsifat baru dan memiliki sifat unggul yang tidak dimiliki oleh tanaman induknya dengan hasil yang tak terduga (Aisyah, 2009; Parry et al., 2009). Menurut Iwo et al. (2013) mutasi induksi menjadi cara yang telah terbukti untuk menimbulkan keragaman dalam varietas tanaman terhadap sifat yang diinginkan baik yang tidak dapat dinyatakan dalam sifat asal atau yang telah hilang selama evolusi.

Beberapa hasil penelitian menunjukkan bahwa terdapat perubahan kualitatif tanaman akibat iradiasi sinar gamma yaitu perubahan warna daun pada tanaman $C$. blumei kuning/hijau menjadi warna merah muda (Aisyah et al., 2015) dan perubahan warna, bentuk dan tepi petal pada tanaman anyelir (Aisyah et al., 2009). Untuk itu, pengembangan tanaman $C$. blumei perlu dirakit keragamannya melalui mutasi induksi fisik dengan iradiasi sinar gamma. Penelitian ini bertujuan untuk mengidentifikasi keragaman genetik, perubahan penampilan dan mendapatkan tanaman mutan putatif pada $C$. blumei melalui iradiasi sinar gamma.

\section{BAHAN DAN METODE}

Penelitian dilaksanakan pada bulan Juli 2014 sampai Juli 2015. Pemberian iradiasi sinar gamma Cobalt 60 dilakukan di IRPASENA (Iradiator Panorama Serba Guna) BATAN (Badan Tenaga Nuklir Nasional) Pasar Jumat, Jakarta. Penanaman dilakukan di kebun percobaan Kelurahan Mulyaharja, Kecamatan Bogor Selatan, Kota Bogor, Jawa Barat.

Penelitian menggunakan Rancangan Kelompok Lengkap Teracak (RKLT) faktor tunggal dengan tiga ulangan.Bahan tanam yang digunakan adalah stek pucuk $C$. blumei warna ungu/hijau. Stek pucuk yang diradiasi adalah stek pucuk berumur 3 minggu yang telah memiliki akar dan dua pasang daun. Iradiasi yang diberikan dilakukan terbagi atas 2 kali penyinaran, penyinaran kedua dilakukan setelah satu jam penyinaran iradiasi pertama. Dosis iradiasi terdiri atas 5 taraf yaitu 0 Gy (kontrol), 20+20 Gy, 22.5+22.5 Gy, 25+25 Gy dan 27.5+27.5 Gy.

Penelitian terdiri atas 3 percobaan. Percobaan 1 merupakan populasi tanaman pertama yang ditanam di lapangan setelah tanaman diradiasi yang disebut populasi MV1 $(\mathrm{M}=$ mutan; $\mathrm{V} 1=$ vegetatif generasi pertama). Percobaan 2 menggunakan tanaman hasil perbanyakan stek pucuk MV1 yang disebut MV2 dan percobaan 3 menggunakan tanaman hasil perbanyakan stek pucuk MV2 yang disebut MV3. Waktu penyetekan antara MV1 ke MV2 dan MV2 ke MV3 adalah 3 bulan setelah ditanam di lapangan dengan jarak 30 $\mathrm{cm}$ x $20 \mathrm{~cm}$. Pemeliharaan yang dilakukan meliputi pembumbunan, penyiraman, pengendalian hama dan penyiangan gulma. 
Pengamatan pada karakter kuantitatif meliputi tinggi tanaman, jumlah daun dan jumlah cabang. Data kuantitatif yang diperoleh pada generasi MV1, MV2 dan MV3 dianalisis menggunakan uji $\mathrm{F}$. Uji lanjut menggunakan uji DMRT (Duncan MultipleRange Test) pada taraf 5\%. Pengamatan parameter genetik dilakukan pada generasi MV2 dan MV3 meliputi koefisien keragaman fenotipe (KKF), koefisien keragaman genetik (KKG) dan heritabilitas arti luas $\left(\mathrm{h}^{2}{ }_{\mathrm{bs}}\right)$.

$\mathrm{KKF}=\frac{\sqrt{\sigma_{\mathrm{f}}^{2}}}{\bar{x}} \times 100 \%$

$\mathrm{KKG}=\frac{\sqrt{\sigma_{\mathrm{g}}^{2}}}{\bar{x}} \times 100 \%$

$\mathrm{h}^{2}{ }_{(\mathrm{bs})}=\frac{\sigma_{\mathrm{g}}^{2}}{\sigma_{\mathrm{f}}^{2}} \times 100 \%$

Pengamatan pada karakter kualitatif meliputi keragaan fenotipik khususnya pada perubahan penampilan tanaman berupa warna dan bentuk tepi daun.Warna daun diukur menggunakan RHS Mini Colour Chart.

\section{HASIL DAN PEMBAHASAN}

\section{Keragaan Karakter Kuantitatif C. blumei Ungu/Hijau Generasi MV1, MV2 dan MV3}

Hasil pengamatan keragaan karakter kuantitatif tinggi tanaman, jumlah daun dan jumlah cabang pada $C$. blumei ungu/hijau generasi MV1, MV2 dan MV3 diperlihatkan pada Tabel 1. Pada generasi MV1, perlakuan iradiasi dengan dosis $20+20$ Gy dan $22.5+22.5$ Gy menyebabkan tinggi tanaman yang berbeda nyata terhadap perlakuan dosis $25+25$ Gy dan 27.5+27.5 Gy. Begitupun juga pada karakter jumlah daun, sedangkan pada karakter jumlah cabang semua perlakuan iradiasi tidak menunjukkan perbedaan yang nyata.

Pada generasi MV2, perlakuan iradiasi dengan dosis $20+20$ Gy sampai $25+25$ Gy tidak menyebabkan perbedaan yang nyata terhadap tinggi tanaman, jumlah daun dan jumlah cabang, tetapi perlakuan dosis tertinggi yaitu 27.5+27.5 Gy menyebabkan rata-rata terendah terhadap tinggi tanaman, jumlah daun dan jumlah cabang dibandingkan dengan tanaman kontrol. Sawangmee et al. (2011) melaporkan bahwa terjadi pengurangan jumlah cabang pada tanaman torenia yang diradiasi dengan dosis yang lebih dari $50 \mathrm{~Gy}$. Pemberian dosis iradiasi 60 Gy menurunkan perkecambahan, tinggi tanaman, jumlah dan lebar daun kunyit dibandingkan dengan dosis yang lebih rendah (Ilyas dan Naz, 2014). Peningkatan dosis iradiasi juga telah dilaporkan menghambat pertumbuhan tinggi tanaman kunyit (Anshori et al., 2014), selain itu mengurangi tinggi tanaman, jumlah daun, berat segar bahkan kematian eksplan mawar (Moharrami et al., 2015).

Tabel 1. Rata-rata tinggi tanaman, jumlah daun dan jumlah cabang C. blumei ungu/hijau generasi MV1, MV2 dan MV3 hasil iradiasi sinar gamma

\begin{tabular}{|c|c|c|c|c|}
\hline \multirow{3}{*}{ Karakter } & \multicolumn{4}{|c|}{ C. blumei Ungu/Hijau } \\
\hline & \multirow{2}{*}{ Dosis Iradiasi (Gy) } & \multicolumn{3}{|c|}{ Generasi } \\
\hline & & MV1 & MV2 & MV3 \\
\hline \multirow{5}{*}{ Tinggi tanaman $(\mathrm{cm})$} & 0 & $23.7 \mathrm{a}$ & 55.7 a & $44.0 \mathrm{a}$ \\
\hline & $20+20$ & $16.3 \mathrm{bc}$ & $40.1 \mathrm{bc}$ & $26.0 \mathrm{~b}$ \\
\hline & $22.5+22.5$ & $18.5 \mathrm{~b}$ & $45.1 \mathrm{ab}$ & $34.0 \mathrm{ab}$ \\
\hline & $25+25$ & $12.4 \mathrm{~d}$ & $33.3 \mathrm{bc}$ & $27.6 \mathrm{~b}$ \\
\hline & $27.5+27.5$ & $14.1 \mathrm{~cd}$ & 30.9 c & $22.5 \mathrm{~b}$ \\
\hline \multirow[t]{5}{*}{ Jumlah daun } & 0 & $21.9 \mathrm{a}$ & $78.8 \mathrm{a}$ & $47.3 \mathrm{a}$ \\
\hline & $20+20$ & $14.9 \mathrm{bc}$ & $56.2 \mathrm{~b}$ & $42.2 \mathrm{a}$ \\
\hline & $22.5+22.5$ & $16.9 \mathrm{ab}$ & $55.5 \mathrm{~b}$ & $36.7 \mathrm{ab}$ \\
\hline & $25+25$ & $10.3 \mathrm{c}$ & $40.8 \mathrm{bc}$ & $35.5 \mathrm{ab}$ \\
\hline & $27.5+27.5$ & $10.7 \mathrm{c}$ & $33.3 \mathrm{c}$ & $23.7 \mathrm{~b}$ \\
\hline \multirow[t]{5}{*}{ Jumlah cabang } & 0 & $2.2 \mathrm{a}$ & $7.5 \mathrm{a}$ & $4.9 \mathrm{a}$ \\
\hline & $20+20$ & $1.1 \mathrm{~b}$ & $5.4 \mathrm{ab}$ & $4.0 \mathrm{a}$ \\
\hline & $22.5+22.5$ & $1.1 \mathrm{~b}$ & $5.8 \mathrm{ab}$ & $3.2 \mathrm{a}$ \\
\hline & $25+25$ & $0.3 \mathrm{~b}$ & $4.3 \mathrm{bc}$ & $3.4 \mathrm{a}$ \\
\hline & $27.5+27.5$ & $0.2 \mathrm{~b}$ & $3.0 \mathrm{c}$ & $2.0 \mathrm{a}$ \\
\hline
\end{tabular}

Keterangan: Angka-angka yang diikuti huruf yang sama pada kolom dan karakter yang sama tidak berbeda nyata berdasarkan uji DMRT pada taraf 5\%. 
Secara umum, pada generasi MV3 semua perlakuan iradiasi tidak menunjukkan perbedaan yang nyata dalam tinggi tanaman, jumlah daun dan jumlah cabang, akan tetapi secara visual tanaman dengan perlakuan dosis tertinggi menunjukkan pertumbuhan yang lebih lambat. Akibatnya menghambat pertambahan tinggi tanaman, jumlah daun dan jumlah cabang terhambat. Hasil penelitian ini menunjukkan bahwa pemberian dosis iradiasi yang tinggi pada $C$. blumei ungu/hijau dapat menghambat pertumbuhannya. Ramesh et al. (2014) menyatakan bahwa terhambatnya pertumbuhan tanaman hasil iradiasi disebabkan oleh kerusakan sel dan kromosom yang berbanding lurus dengan peningkatan konsentrasi mutagen. Adanya pengaruh yang nyata dari perlakuan iradiasi pada generasi MV1, MV2 maupun MV3 membuktikan bahwa efek iradiasi terhadap karakter pertumbuhan tanaman masih terjadi walaupun sudah di generasi MV2 dan MV3. Hasil yang sama dilaporkan oleh Aisyah (2009) bahwa tanaman anyelir hasil iradiasi yang telah disubkultur sebanyak lima kali masih menunjukkan perbedaan tinggi planlet.

\section{Keragaman Genetik C. blumei Ungu/Hijau Hasil Iradiasi Sinar Gamma Generasi MV2 dan MV3}

Keragaman setiap individu dalam populasi tanaman merupakan faktor keberhasilan mutasi. Keragaman genetik $C$. blumei ungu/hijau hasil iradiasi dapat diamati pada generasi MV2 dan MV3 dengan melihat nilai parameter genetik. Nilai keragaman untuk karakter kuantitatif dapat diketahui berdasarkan nilai koefisien keragaman fenotipe (KKF) dan koefisien keragaman genetik (KKG). Selanjutnya, heritabilitas merupakan parameter genetik yang digunakan untuk mengukur kemampuan suatu genotipe dalam populasi tanaman dalam mewariskan karakter yang dimilikinya. Kriteria nilai duga KKF dan KKG adalah rendah $(0 \% \leq 25 \%)$, sedang $(25 \% \leq 50 \%)$, cukup tinggi $(50 \% \leq$ $75 \%$ ) dan tinggi $(75 \% \leq 100 \%)$ (Sari et al., 2014). Kriteria nilai duga heritabilitas $\left(h^{2}\right)$ dalam arti luas adalah tinggi $\left(\mathrm{h}^{2} \geq 50 \%\right)$, sedang $\left(20 \% \leq \mathrm{h}^{2}<50 \%\right)$ dan rendah $\left(\mathrm{h}^{2}<\right.$ 20\%) (Mangoendidjojo, 2003).

Pada generasi MV2, nilai KKF dan KKG tertinggi diperlihatkan pada karakter jumlah cabang dosis $25+25$ Gy dengan nilai 66.57 dan $59.16 \%$, hasil ini menunjukkan nilai keragaman yang cukup tinggi. Nilai heritabilitas berkisar antara $0-90.18 \%$ (Tabel 2). Nilai heritabilitas yang tinggi diperlihatkan pada karakter tinggi tanaman dosis $20+20 \mathrm{~Gy}$, $22.5+22.5$ Gy dan $25+25$ Gy, jumlah daun dosis $20+20$ Gy dan $22.5+22.5$ Gy serta jumlah cabang dosis $20+20 \mathrm{~Gy}, 22.5+22.5$ Gy dan $25+25$ Gy. Pada generasi MV3, nilai KKF dan KKG berkisar antara 8.11-90.18\% dan 0$74.02 \%$. Nilai KKF dan KKG tertinggi diperlihatkan pada karakter jumlah cabang dosis $25+25$ Gy yaitu $90.18 \%$ dan $74.02 \%$. Nilai KKG yang tinggi menandakan karakter yang diamati memiliki keragaman genetik yang luas (Herawati et al., 2009). Nilai heritabilitas yang tinggi diperlihatkan pada karakter jumlah daun dan jumlah cabang dosis $20+20$ Gy, $22.5+22.5$ Gy dan $25+25$ Gy (Tabel 3).

Tabel 2. Nilai parameter genetik tanaman C. blumei ungu/hijau generasi MV2

\begin{tabular}{|c|c|c|c|c|c|}
\hline \multirow{2}{*}{\multicolumn{2}{|c|}{ Karakter/Parameter Genetik }} & \multicolumn{4}{|c|}{ C. blumei Ungu/Hijau MV2 } \\
\hline & & \multicolumn{4}{|c|}{ Dosis Iradiasi (Gy) } \\
\hline & & $20+20$ & $22.5+22.5$ & $25+25$ & $27.5+27.5$ \\
\hline \multirow[t]{3}{*}{ Tinggi tanaman } & $\mathrm{KKF}(\%)$ & $28.69^{S}$ & $28.40^{\mathrm{S}}$ & $32.46^{\mathrm{S}}$ & $16.56^{\mathrm{R}}$ \\
\hline & $\mathrm{KKG}(\%)$ & $26.74^{\mathrm{S}}$ & $26.97^{\mathrm{S}}$ & $29.94^{\mathrm{S}}$ & $10.10^{\mathrm{R}}$ \\
\hline & $\mathrm{h}_{(\mathrm{bs})}^{2}(\%)$ & $86.83^{\mathrm{T}}$ & $90.18^{\mathrm{T}}$ & $85.09^{\mathrm{T}}$ & $37.18^{\mathrm{R}}$ \\
\hline \multirow[t]{3}{*}{ Jumlah daun } & $\operatorname{KKF}(\%)$ & $42.28^{\mathrm{S}}$ & $41.23^{\mathrm{S}}$ & $41.96^{\mathrm{S}}$ & $29.42^{\mathrm{S}}$ \\
\hline & $\mathrm{KKG}(\%)$ & $36.96^{\mathrm{S}}$ & $29.92^{\mathrm{S}}$ & $10.64^{\mathrm{R}}$ & $0.00^{\mathrm{R}}$ \\
\hline & $\mathrm{h}_{(\mathrm{bs})}^{2}(\%)$ & $61.11^{\mathrm{T}}$ & $52.65^{\mathrm{T}}$ & $6.44^{\mathrm{R}}$ & $0.00^{\mathrm{R}}$ \\
\hline \multirow[t]{3}{*}{ Jumlah cabang } & $\operatorname{KKF}(\%)$ & $50.07^{\mathrm{S}}$ & $40.52^{\mathrm{S}}$ & $66.57^{\mathrm{CT}}$ & $32.08^{\mathrm{S}}$ \\
\hline & $\mathrm{KKG}(\%)$ & $43.92^{\mathrm{S}}$ & $34.42^{\mathrm{s}}$ & $59.16^{\mathrm{CT}}$ & $0.00^{\mathrm{R}}$ \\
\hline & $\mathrm{h}_{(\mathrm{bs})}^{2}(\%)$ & $76.95^{\mathrm{T}}$ & $72.17^{\mathrm{T}}$ & $78.98^{\mathrm{T}}$ & $0.00^{\mathrm{R}}$ \\
\hline
\end{tabular}

Keterangan: $\mathrm{KKF}=$ koefisien keragaman fenotipe, $\mathrm{KKG}=$ koefisien keragaman genetik, $\mathrm{h}^{2}{ }_{(\mathrm{bs})}=$ heritabilitas arti luas, kriteria parameter genetik $\mathrm{S}=$ sedang, $\mathrm{R}=$ rendah. $\mathrm{CT}=$ cukup tinggi, $\mathrm{T}=$ tinggi. 
Tabel 3. Nilai parameter genetik tanaman C. blumei ungu/hijau generasi MV3

\begin{tabular}{|c|c|c|c|c|c|}
\hline \multirow{2}{*}{\multicolumn{2}{|c|}{ Karakter/Parameter Genetik }} & \multicolumn{4}{|c|}{ C. blumei Ungu/Hijau MV3 } \\
\hline & & \multicolumn{4}{|c|}{ Dosis Iradiasi (Gy) } \\
\hline & & $20+20$ & $22.5+22.5$ & $25+25$ & $27.5+27.5$ \\
\hline \multirow[t]{3}{*}{ Tinggi tanaman } & $\mathrm{KKF}(\%)$ & $26.11^{\mathrm{S}}$ & $37.76^{\mathrm{S}}$ & $30.83^{S}$ & $22.98^{\mathrm{R}}$ \\
\hline & $\mathrm{KKG}(\%)$ & $23.65^{\mathrm{R}}$ & $36.87^{\mathrm{S}}$ & $28.88^{\mathrm{S}}$ & $19.25^{\mathrm{R}}$ \\
\hline & $\mathrm{h}_{(\mathrm{bs})}^{2}(\%)$ & $82.05^{\mathrm{T}}$ & $95.35^{\mathrm{T}}$ & $87.78^{\mathrm{T}}$ & $70.16^{\mathrm{R}}$ \\
\hline \multirow[t]{3}{*}{ Jumlah daun } & $\mathrm{KKF}(\%)$ & $37.25^{\mathrm{s}}$ & $50.91^{\mathrm{S}}$ & $64.84^{\mathrm{S}}$ & $35.83^{\mathrm{S}}$ \\
\hline & $\mathrm{KKG}(\%)$ & $29.63^{s}$ & $44.38^{\mathrm{s}}$ & $58.48^{\mathrm{s}}$ & $0.00^{\mathrm{R}}$ \\
\hline & $\mathrm{h}_{(\mathrm{bs})}^{2}(\%)$ & $63.28^{\mathrm{T}}$ & $76.01^{\mathrm{T}}$ & $81.34^{\mathrm{T}}$ & $0.00^{\mathrm{R}}$ \\
\hline \multirow[t]{3}{*}{ Jumlah cabang } & $\mathrm{KKF}(\%)$ & $69.81^{\mathrm{CT}}$ & $84.53^{\mathrm{T}}$ & $90.18^{\mathrm{T}}$ & $88.19^{\mathrm{T}}$ \\
\hline & $\mathrm{KKG}(\%)$ & $53.47^{\mathrm{CT}}$ & $68.97^{\mathrm{CT}}$ & $74.02^{\mathrm{CT}}$ & $10.54^{\mathrm{R}}$ \\
\hline & $\mathrm{h}_{(\mathrm{bs})}^{2}(\%)$ & $58.68^{\mathrm{T}}$ & $66.57^{\mathrm{T}}$ & $67.38^{\mathrm{T}}$ & $1.43^{\mathrm{R}}$ \\
\hline
\end{tabular}

Keterangan: $\mathrm{KKF}=$ koefisien keragaman fenotipe, $\mathrm{KKG}=$ koefisien keragaman genetik, $\mathrm{h}^{2}{ }_{(\mathrm{bs})}=$ heritabilitas arti luas, kriteria parameter genetik $\mathrm{S}=$ sedang, $\mathrm{R}=$ rendah. $\mathrm{CT}=$ cukup tinggi, $\mathrm{T}=$ tinggi.

Berdasarkan Tabel 2 dan 3 diperlihatkan bahwa seluruh karakter yang diamati memiliki nilai heritabilitas antara rendah-tinggi. Karakter dengan nilai heritabilitas tinggi menunjukkan karakter lebih dominan dipengaruhi oleh faktor genetik dibandingkan faktor lingkungan, sebaliknya karakter dengan nilai heritabilitas yang rendah menunjukkan faktor lingkungan yang lebih mempengaruhi karakter tanaman (Hartati et al., 2012; Rahajeng dan Rahayuningsih, 2015).

\section{Keragaan Karakter Kualitatif C. blumei Ungu/Hijau Generasi MV1, MV2 dan MV3}

Perlakuan iradiasi menghasilkan tanaman mutan putatif dari generasi MV1, MV2 sampai generasi MV3 (Gambar 1). Tanaman mutan putatif dengan notasi 22.5+22.5.8 (MV1-3) merupakan mutan putatif yang dihasilkan pada perlakuan iradiasi dengan dosis $22.5+22.5$ Gy tanaman kedelapan generasi pertama sampai generasi ketiga. Tanaman mutan putatif masing-masing dihasilkan pada tanaman 20+20.1 (MV1), 25+25.14 (MV1), 20+20.10 (MV2), 25+25.10 (MV2), 20+20.5 (MV2-3), 20+20.7 (MV2-3), 22.5+22.5.8 (MV1-3), 25+25.5 (MV1-3), 25+25.8 (MV1-3) (Gambar 1). Tanaman mutan putatif 22.5+22.5.8 (MV1-3) dan 25+25.8 (MV1-3) memperlihatkan bentuk tepi daun yang berubah dari bergelombang (kontrol) menjadi agak berigi (Gambar 1g dan 1i). Hasil penelitian ini menunjukkan bahwa dari 9 tanaman mutan putatif yang dihasilkan hanya 5 mutan putatif yang stabil sampai generasi MV3 (Gambar 1e, if, ig, ih dan 1i).Tanaman mutan putatif $20+20.1$ dan $25+25.14$ mengalami mutasi balik pada generasi MV2 (Gambar 1a dan 1b). Tanaman mutan putatif $20+20.10$ dan 25+25.10 mengalami mutasi balik pada generasi MV3 (Gambar 1c dan 1d).

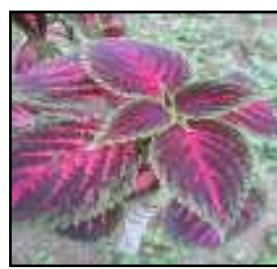

Kontrol

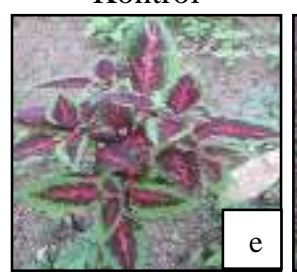

20+20.5, MV2-3

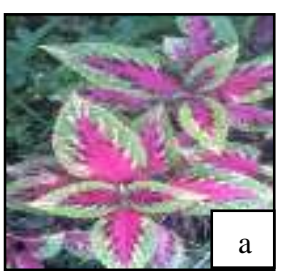

20+20.1, MV1

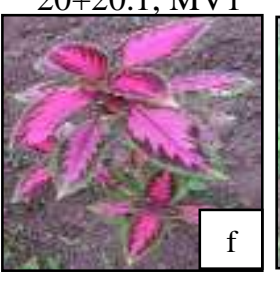

20+20.7, MV2-3
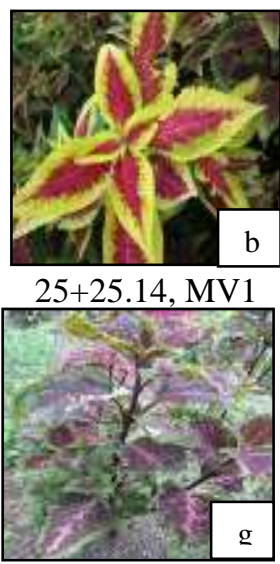

$22.5+22.5 .8$, MV1-3 25+25.5, MV1-3

$20+20.10$, MV2

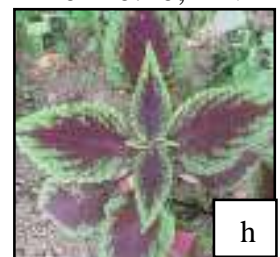

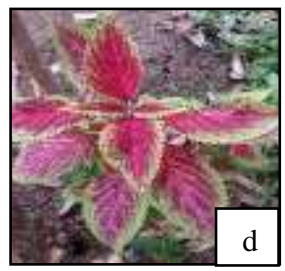

$25+25.10, \mathrm{MV} 2$

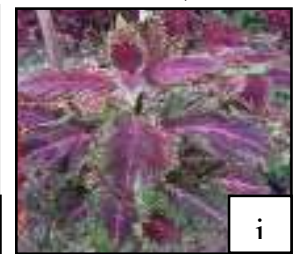

25+25.8, MV1-3

Gambar 1. Perubahan kualitatif $C$. blumei ungu/hijau hasil iradiasi sinar gamma 
Tabel 4. Perbandingan warna daun mutan C. blumei ungu/hijau hasil iradiasi sinar gamma dengan kontrolnya pada generasi MV3

\begin{tabular}{|c|c|c|}
\hline $\begin{array}{l}\text { C. blumei } \\
\text { Ungu/Hijau }\end{array}$ & Notasi & Warna Daun \\
\hline Kontrol & Kontrol & $\begin{array}{l}\text { Purple red RHS N57A/dark green RHS 137A/dark purple } \\
\text { brown RHS N77A }\end{array}$ \\
\hline Mutan putatif 1 & $20+20.5$ & $\begin{array}{l}\text { Dark purple brown RHS 187A/green RHS 137C/purple red } \\
\text { RHS } 58 B\end{array}$ \\
\hline Mutan putatif 2 & $20+20.7$ & Purple pink RHS 73A/dark green RHS 144A \\
\hline Mutan putatif 3 & $22.5+22.5 .8$ & $\begin{array}{l}\text { Dark purple brown RHS N77A/green RHS 144A/purple red } \\
\text { RHS } 55 \mathrm{~A}\end{array}$ \\
\hline Mutan putatif 4 & $25++25.5$ & Dark purple brown RHS N77A/green RHS 144A \\
\hline Mutan putatif 5 & $25+25.8$ & $\begin{array}{l}\text { Purple brown RHS 166A/green RHS 144A/purple red RHS } \\
55 \mathrm{~A}\end{array}$ \\
\hline
\end{tabular}

Adanya mutasi balik diduga karena perubahan yang dihasilkan belum stabil atau mengalami fenomena diplontic selection. Diplontic selection merupakan perubahan fenotipe yang terjadi pada tanaman yang teradiasi namun tidak bertahan lama karena sel-sel mutannya saling berkompetisi dengan sel-sel normal (Aisyah et al., 2009). Jika sel yang termutasi dapat bertahan maka sel normal akan menghilang dan sel mutan akan terus berkembang menghasilkan penampilan baru pada tanaman, namun apabila sel mutan tidak mampu bertahan maka penampilan tanaman akan normal kembali karena sel normal mampu bertahan dan bisa berkembang dengan baik(Datta, 2012).

Secara keselurahan pada generasi MV3 dihasilkan 5 mutan putatif stabil C. blumei ungu/hijau. Mutan putatif $1 \quad(20+20.5)$ menghasilkan daun yang lebih kecil dan warna hijau yang lebih dominan pada tepi daun, mutan putatif $2(20+20.7)$ menghasilkan warna merah muda yang lebih dominan pada bagian tengah daunnya, mutan putatif $3(22.5+22.5 .8)$ menghasilkan tepi daun yang berigi dan warna ungu yang lebih gelap, mutan putatif 4 $(25+25.5)$ menghasilkan warna ungu yang lebih gelap dan corak warna bagian tengah permukaan daunnya menghilang, dan mutan putatif $5(25+25.8)$ juga menghasilkan tepi daun yang berigi dengan warna ungu gelap yang lebih dominan pada permukaan daunnya (Gambar 1e, 1f, 1g, 1h dan 1i). Perbedaan warna daun mutan putatif dan kontrol $C$. blumei ungu/hijau berdasarkan RHS mini chart colour disajikan pada Tabel 4.
Perubahan bentuk daun akibat iradiasi sinar gamma diduga karena berkembangnya sel mutan abnormalitas menjadi jaringan dan organ yang berbeda dari sel induknya (Cahyo dan Dinarti, 2015), sedangkan perubahan warna daun disebabkan karena gangguan fisiologi pada saat sintesis klorofil (Datta, 2012). Berbagai penelitian telah menghasilkan perubahan kualitatif pada tanaman hasil iradiasi diantaranya dilaporkan oleh Hasbullah et al. (2012) bahwa iradiasi sinar gamma mempengaruhi perubahan warna kalus pada tanaman hias Gerbera jamesonii dari putih menjadi coklat tua dan perubahan warna daun dari hijau tua menjadi hijau muda. Singh dan Anjana (2015) menghasilkan mutan gladiol warna kuning muda pada generasi MV3. Romeida (2012) dari hasil penelitiannya dengan iradiasi sinar gamma mendapatkan 9 mutan anggrek $S$. plicata potensial berdasarkan perbedaan bentuk dan warna daun serta bentuk dan warna bunga, selain itu diperoleh keragaman bentuk dan warna plb dan planlet anggrek dengan kisaran dosis 3070 Gy.

\section{KESIMPULAN}

Pemberian iradiasi sinar gamma pada $C$. blumei ungu/hijau menghasilkan keragaman genetik yang cukup tinggi pada karakter jumlah daun dan jumlah cabang. Karakter jumlah daun dengan nilai KKG $58.48 \%$ pada dosis $25+25$ Gy serta karakter jumlah cabang dengan nilai KKG $53.47 \%$, $68.97 \%$ dan $74.02 \%$ masing-masing pada dosis $20+20 \mathrm{~Gy}$, 
$22.5+22.5$ dan $25+25$ Gy. Mutasi induksi fisik dengan iradiasi sinar gamma pada $C$. blumei ungu/hijau menghasilkan 5 mutan putatif berdasarkan perubahan warna dan corak daun yaitu pada tanaman $20+20.5,20+20.7$, $22.5+22.5 .8,25+25.5$ dan $25+25.8$.

\section{DAFTAR PUSTAKA}

Aisyah, S.I., H. Aswidinnoor, A. Saefuddin. 2009. Induksi mutasi stek pucuk anyelir (Dianthus caryophyllus Linn.). J. Agron. Indonesia. 37(1): 62-70.

Aisyah, S.I., Y. Marthin, M.R.M. Damanik. 2015. Improvement of coleus performance through mutation induction using gamma ray irradiation. J. Tropical. Crop. Sci. 2(1): 1-7.

Anshori S.R., S.I. Aisyah, L.K. Darusman. 2014. Induksi mutasi fisik dengan iradiasi sinar gamma pada kunyit (Curcuma domestica Val). J. Hort. Indonesia. 5(3): 84-94.

Cahyo, F.A., D. Dinarti. 2015. Pengaruh iradiasi sinar gamma terhadap pertumbuhan protocorm like bodies anggrek Dendrobium lasianthera (JJ. Smith) secara in vitro. J. Hort. Indonesia. 6(3): 177-186.

Chung, B.N., G.S. Choi. 2008. Incidence of Coleus blumei viroid in seeds of commercial coleus in Korea. Plant Pathology. J. 24(3): 305-308.

Datta, S.K. 2012. Success story of induced mutagenesis for development of new ornamental varieties. Biodiversity and Bioavailability. 6(1): 15-26.

Djajanegara, I., P. N. Wahyudi, Widyastuti, Harsoyo. 2007. Pengaruh mutasi dengan sinar gamma $\left(\mathrm{Co}^{60}\right)$ terhadap produktivitas jamur tiram abu-abu (Pleurotus sajurcaju). Berk. Penel. Hayati. 13: 57-61.

Handayati, W. 2013.Perkembangan pemuliaan mutasi tanaman hias di Indonesia. Jurnal Ilmiah Aplikasi Isotop dan Radiasi. 9(1): 67-80.
Hartati, R.S., A. Setiawan, B. Heliyanto, Sudarsono. 2012. Keragaman genetik, heritabilitas dan korelasi antar karakter 10 genotipe terpilih jarak pagar (Jatropha curcas L.). J. Littri. 18(2): 74-80.

Hasbullah, N.A., R.M. Taha, A. Saleh, M. Noraini. 2012. Irradiation effect on in vitro organogenesis, callus growth and plantlet development of Gerbera jamesonii. Hort. Bras. 30(2): 252-257.

Herawati, R., B.S. Purwoko, I.S. Dewi. 2009. Keragaman genetik dan karakter agronomi galur haploid ganda padi gogo dengan sifat-sifat tipe baru hasil kultur antera. J. Agron. Indonesia. 37(2): 87-94.

Ilyas, S., S. Naz. 2014. Effect of gamma irradiation on morphological character and isolation of curcuminoids and oleoresins of Curcuma longa L. J. Anim. Plant Sci. 24(5): 1396-1404.

Iwo, G.A., C.O. Amadi, C.O. Eleazu, J.U. Ukpabi. 2013. Induced mutagenesis on ginger for improved yield components and oleoresin content. Canadian J. Plant. Breeding.1(3): 90-96.

Loutfy, I., E. Juhany, A. Abdullah, A. Harby. 2013. Status and diversity of ornamental plants in King Saud University campus at Riyadh, Saudi Arabia. AmericanEurasian J. Agric. \& Environ. Sci. 13(4): 471-478.

Mangoendidjojo, W. 2003. Dasar-dasar Pemuliaan Tanaman. Kanisius. Yogyakarta.

Moharrami, M., S. Vadadi, M.A. Ebrahimi. 2015. Effect of various levels of gamma irradiation on some characteristicsof roseseedling. Intl. Res. J. Appl. Basic. Sci. 9(9): 1460-1464.

Parry, M.A.J., P.J. Madgwick, C. Bayon, K. Tearall, L.A. Hernandez, M. Baudo, M. Rakszegi, W. Hamada, A. AlYassin, H. Ouabbou, M. Labhilili, A.L. Philips. 2009. Mutation discovery for crop improvement. J Experimental Botany. 60(10): 2817-2825. 
Ramesh, H.L., V.N.Y. Murthy, Munirajappa. 2012. Effect of gamma radiation on morphological and growth parameters of mulberry variety $\mathrm{M}_{5}$. International Journal of Science and Nature. 3(2): 447-452.

Rahajeng, W., S.A. Rahayuningsih. 2015. Pendugaan komponen ragam, heritabilitas dan korelasi klon-klon harapan ubi jalar berkadar betakaroten tinggi. J. Ilmu Pertanian. 18(1): 51-55.

Romeida, A. 2012. Induksi mutasi dengan iradiasi sinar gamma untuk pengembangan klon unggul anggrek Spathoglottis plicata Blume aksesi Bengkulu. [Disertasi]. Sekolah Pasca Sarjana. Institut Pertanian Bogor. Bogor.

Rumbiak, O., J. Nunaki, H. Salaosa, S. Sutarno. 2009. Variasi Coleus sp dan pemanfaatannya oleh suku Hattam di Kampung Gueintuy distrik Warmare Kabupaten Manokwari. FMIPA. Universitas Papua.
Sari, L., A. Parwito, D. Sopandie, R Purnamaningsih, E. Sudarmanowati. 2015. Pengaruh irradiasi sinar gamma pada pertumbuhan kalus dan tunas tanaman gandum (Triticum aestivum L.). J. Ilmu Pertanian. 18(1): 44-50.

Sawangmee, W., T. Taychasinpitak, P. Jompuk. S. Kikuchi. 2011. Effects of gamma ray irradiation in plant morphology of interspecific hybrids between Torenia fournieri and Torenia baillonii. Kasetsart J. Nat. Sci. 45: 803810.

Singh, A.K., S. Anjana. 2015. Effect of gamma irradiation on morphological changes, flowering and induced mutants in gladiolus. Indian Journal of Horticulture. 72(1): 84-87.

Suprasanna, P., H. Nakagawa. 2013. Mutation breeding of vegetatively propagated crops. In: Shu, Forster BP, Nakagawa H. editor. Plant Mutation Breeding and Biotechnology. Food and Agriculture Organization of the United Nations; 2012; Rome, Italy, Austria (AT): FAO/IAEA. p. 347-358. 